\title{
Patterns of biomass allocation between foliage and woody structure: the effects of tree size and specific functional traits
}

\author{
S. Mensah, R. Glèlè Kakaï, T. Seifert
}

Mensah, S., Glèlè Kakaï, R., Seifert, T., 2016. Patterns of biomass allocation between foliage and woody structure: the effects of tree size and specific functional traits. Ann. For. Res. 59(1): 49-60.

Abstract. Biomass allocation is closely related to species traits, resources availability and competitive abilities, and therefore it is often used to capture resource utilisation within plants. In this study, we searched for patterns in biomass allocation between foliage and wood (stem plus branch), and how they changed with tree size (diameter), species identity and functional traits (leaf area and specific wood density). Using data on the aboveground biomass of 89 trees from six species in a Mistbelt forest (South Africa), we evaluated the leaf to wood mass ratio (LWR). The effects of tree size, species identity and specific traits on LWR were tested using Generalised Linear Models. Tree size (diameter) was the main driver of biomass allocation, with $44.43 \%$ of variance explained. As expected, LWR declined significantly with increasing tree diameter. Leaf area (30.17\% explained variance) and wood density (12.61\% explained variance) also showed significant effects, after size effect was accounted for. Results also showed clear differences among species and between groups of species. Per unit of wood mass, more biomass is allocated to the foliage in the species with the larger leaf area. Inversely, less biomass is allocated to the foliage in species with higher wood density. Moreover, with increasing diameter, lower wood density species tended to allocate more biomass to foliage and less biomass to stems and branches. Overall, our results emphasise the influence of plant size and functional traits on biomass allocation, but showed that neither tree diameter and species identity nor leaf area and wood density are the only important variables.

Keywords aboveground biomass, leaf area, leaf to wood mass ratio, Mistbelt forest, South Africa, partitioning, species identity, trunk diameter, wood density.

Authors. Sylvanus Mensah (sylvanus.m89@gmail.com), Thomas Seifert - Department of Forest and Wood Sciences, Stellenbosch University, South Africa; Sylvanus Mensah, Romain Glèlè Kakaï - Laboratory of Biomathematics and Forest Estimations.

Manuscript received October 11, 2015; revised February 08, 2016; accepted February 12, 2016; online first March 21, 2016. 


\section{Introduction}

Biomass production is a primary function of forest ecosystems that is influenced by an interplay of processes: roots capture nutrients from soil, stems and branches provide mechanical support and conduct water with nutrients, and leaves fix carbon (Poorter et al. 2012). Because plants have to balance the allocation of resources to roots, stem, branches and leaves in a way to enable necessary physiological activities for the functioning of these organs, only plants that are successful in acquisition of resources will maintain or achieve a regular growth (Bloom et al. 1985, Shipley \& Meziane 2002). The extent to which acquisition and utilisation of resources vary among taxa would define the limit of plant biomass production (Reich 2002). Therefore, understanding the patterns of biomass partitioning within plants is of high importance in the field of tree physiology and plant ecology, and also has many applications for agriculture/forestry.

Biomass allocation has generally been used to capture resource utilisation by plants in empirical and simulation studies (e.g. Seifert \& Müller-Starck 2009, Pretzsch et al. 2012, Rötzer et al. 2012, Tomlinson et al. 2014, Freschet et al. 2015). According to the optimal partitioning theory (OPT), plants should allocate more biomass to organs that have limited access to resources (Bloom et al. 1985). For instance, in water- and nutrients-limited environments, plants decrease the biomass allocation to foliage with increasing light availability (Shipley \& Meziane 2002, Poorter et al. 2012). Similarly, in nutrient-limited soils, more biomass would be allocated to roots to increase use of water and nutrient resources (Deng et al. 2006, Poorter et al. 2012). Therefore, biomass allocation among plant organs is driven by above and belowground environmental conditions (Müller et al. 2000, Freschet et al. 2015), but plant size (Pino et al. 2002), ontogenic trends (Poorter et al. 2012, Xie et al. 2012), species competitive abilities (Ninkovic 2003,
Dybzinski et al. 2011), species identity and functional traits (McCarthy et al. 2007, Poorter et al. 2015) can also act as potential covariates to define the investment in support tissues.

Many previous studies have emphasised the influence of plant size on biomass allocation (Bonser \& Aarssen 2009, Poorter \& Sack 2012, Xie et al. 2012), regardless of whether root to shoot ratio, or its inverse shoot to root ratio is used (Wilson 1988, Reich 2002, Mokany et al. 2006). The use of root to shoot ratio has the advantage of taking into account the whole plant, however, it condenses the total aboveground biomass into one compartment and therefore limits the investigation on the different organs (e.g. stem, branch, leaves) (Poorter et al. 2012). Whether the generalisation about plant size influence on biomass allocation also applies for aboveground organs alone, has received much less attention so far (Körner 1994, Poorter et al. 2015). In particular, as stem, branches and leaves have different physiological activities (Pearcy et al. 2005), analysing the patterns of biomass allocation between aboveground organs can produce additional information. Accurate quantification of wood (i.e. stem plus branch) and foliage biomass would allow for understanding such patterns, the extent to which they vary among species, groups of species, and according to specific traits.

Species groups, distinguished phylogenetically, morphologically or physiologically, are important because species from different groups may have different specialized strategies to optimize uptake of resources. Depending on plant traits, species are often grouped into woody or herbaceous species, angiosperms or gymnosperms, coniferous or broadleaved, deciduous or evergreen. Specific traits such as wood density, leaf area and maximum height could show strong influence on the allocation patterns (Mokany et al. 2006, Reich 2002). For instance, wood density is a good predictor of individual tree diameter increments (Wright et al. 2010), and correlates con- 
sistently with the biomass increment (Finegan et al. 2015). Besides wood density, specific leaf area is known to be related with the intensity of plant respiration and photosynthesis (Ivetić et al. 2014, Weraduwage et al. 2015), and thus plant growth. In the infancy of its growth, a plant would tend to allocate more resources to leaves so that to allow maximum interception of light and favour fixation of large amounts of $\mathrm{C}$ from atmosphere. As a result, leaf area would co-determine, through the rate of photosynthesis and respiration, the relative growth rate of the plant (Tomlinson et al. 2014).

In this study, we evaluated the biomass allocation to wood (stem plus branch) and foliage using our available data on the aboveground biomass of 89 trees from six species in a Mistbelt forest (South Africa). We expected that tree size, species identity and functional traits would influence the biomass allocation, but we did not know their relative importance.

We first examined the between-species variation in the biomass allocation using the leaf to wood mass ratio (LWR). Because biomass allocation is size dependent, we assessed simultaneously the effects of tree size (diameter at breast height, dbh) and species identity on LWR. We further accounted for the effect of tree size, and tested whether the biomass allocation in the aboveground compartment was influenced by species traits such as, individual leaf area and wood density. Finally, we compared the trend lines of LWR and dbh scaling relationship between groups of species. We tested the hypotheses that (i) LWR decreases with increasing tree diameter, but (ii) the effect of tree size works differently according to the species group. Specifically, we suspected that (iii) the slope of the trend line of LWR-dbh in the group of species with higher leaf area, would be larger than in the one of species with smaller leaf area.

\section{Materials and Methods}

\section{Study area and species}

The study area is located in Limpopo Mistbelt Forests, in South Africa (Mucina \& Rutherford 2006). The study was specifically carried out in Woodbush-De Hoek State Forest (approximately 2350'S, 2959'E), near Tzaneen, in the North Eastern Transvaal (Geldenhuys 2002). The altitude in the area varies between 1050 to $1650 \mathrm{~m}$ above mean sea level. The annual precipitation ranges from 600 and 1800 $\mathrm{mm}$. The vegetation in the Woodbush-De Hoek State Forest is dominated by tree species such as Xymalos monospora (Harv.) Baill. ex Warb, Podocarpus latifolius (Thunb.) R. Br. ex Mirb., Combretum kraussii Hochst., Syzygium gerrardii Burtt Davy, Cryptocarya transvaalensis Burtt Davy in the canopy layer, and by small trees and shrubs like Oxyanthus speciosus DC., Peddiea africana Hook., Oricia bachmannii (Engl.) I. Verd., Kraussia floribunda Harv. in the understorey vegetation. On the basis of leaf area, specific wood density and the relative dominance in the forest, six species were considered for this study. They were Celtis africana Burm. f. (Cannabaceae), Combretum kraussii (Combretaceae), Croton sylvaticus Hochst. (Euphorbiaceae), Syzygium gerrardii (Myrtaceae), Trichilia dregeana Sond. (Meliaceae) and Xymalos monospora (Monimiaceae). C. africana, C. kraussii and C. sylvaticus are deciduous trees while $S$. gerrardii, $T$. dregeana and $X$. monospora are all evergreen species.

\section{Sampling design and laboratory analysis}

Data on aboveground biomass was obtained from tree and branch sampling, individual tree measurement, and laboratory processing from December 2014 to May 2015. Fourteen to fifteen individual trees were selected per species across a wide range of diameter at breast height. In total, 89 individual trees were con- 
sidered.

Because the studied species were protected in South Africa, they were measured and sampled without damaging them. Thus, the diameter was measured on the standing stem at every 2 meters interval up to the crown base, by a professional tree climber. The larger branches (basal diameter $>15 \mathrm{~cm}$ ) were treated as stem section and thus measured at the thick and thin diameter ends. The distance from the thick and thin points was also measured. On the smaller branches (basal diameter $<15 \mathrm{~cm}$ ), only the branch basal diameter was measured. In addition, samples of wood cores were collected at breast height and crown base levels using increment corer, for further determination of wood density. To limit the damages to the tree, two to four branches were sampled at different height levels for each tree, and packed into paper bags for estimation of dry mass of branch wood and foliage. The wood density was obtained by using the water-displacement method and by oven-drying the core samples to equilibrium weight (at $105^{\circ} \mathrm{C}$ until 48 to 72 drying hours). The branch wood and foliage samples were also oven-dried at $105^{\circ} \mathrm{C}$ until their constant weight (Seifert \& Seifert 2014).

\section{Aboveground biomass data and specific traits}

The dry mass of branch foliage was used to estimate for each species, the foliage biomass equations at branch level as a function of branch basal diameter (Mensah et al. unpublished). Based on these specific foliage biomass equations and the branch basal diameter measured on standing trees, the foliage biomass was up-scaled from the branch level to the tree level. The same method was applied for the branch wood to determine the total dry mass of wood in smaller branches at tree level. In addition, the volume of larger branches and standing stems was calculated by applying Smalian's formula (van Laar and Akça 2007), and the average wood density was thus used to calculate the wood biomass for the stem and larger branches. The total aboveground 52 wood mass of each individual tree was then obtained by adding the biomass of stem and larger branches to the total dry mass of wood in smaller branches (Table 1).

The plant traits used in this study were wood density $\left(\mathrm{g} / \mathrm{cm}^{3}\right)$ and individual leaf area $\left(\mathrm{cm}^{2}\right)$. Wood density was obtained from laboratory analyses. Because wood cores were taken from two levels on each standing tree, the averaged wood density was used. The information on leaf area of these species was obtained from TRY database on biological traits (Kattge et al. 2011) and using the Trees of Southern Africa (Coates-Palgrave 2002). In case multiples values were available for a species, the average value was used. C. africana, $C$. kraussii, $S$. gerrardii and $X$. monospora have leaves with smaller area, whereas $C$. sylvaticus and $T$. dregeana have leaves with relatively greater area (Table 1).

\section{Data analysis}

We evaluated the biomass allocation to wood and foliage by calculating for each individual tree, the foliage mass to wood mass ratio (LWR), i.e. the biomass allocated to foliage per unit of wood mass. To assess the effect of species identity, we tested for the difference of LWR among study species through a one-way analysis of variance applied to the log-transformed data. The normal distribution was checked using Shapiro Wilk statistic. Species were post-hoc compared by performing the Student-Newman-Keuls test. Next, we tested whether the size dependency hypothesis of biomass allocation applies for wood and foliage components, and whether there were differences among species. We used a Generalised Linear Model (GLM) to estimate simultaneously, the effects of tree size (i.e., dbh) and species identity. As the distribution of LWR was positively skewed, we fitted the GLM with Gamma family and "log" link. GLMs were also used to examine the relative effects of specific traits (wood density and leaf area) on LWR. To do so, we controlled the variation 
Table 1 Traits of study species and sampled trees

\begin{tabular}{|c|c|c|c|c|c|}
\hline Species & No. trees & $\mathrm{DBH}(\mathrm{cm})$ & $\begin{array}{l}\text { Wood density } \\
\left(\mathrm{g} / \mathrm{cm}^{3}\right)\end{array}$ & $\begin{array}{l}\text { Aboveground } \\
\text { biomass }(\mathrm{kg})\end{array}$ & Leaf phenology \\
\hline C. africana $a^{\mathrm{a}, \mathrm{d}}$ & 15 & $2.80-94.50$ & $0.30-0.65$ & $4.93-8871.97$ & Deciduous \\
\hline C. kraussii $i^{\mathrm{a}, \mathrm{d}}$ & 16 & $1.50-91.00$ & $0.51-0.66$ & $0.26-4590.19$ & Deciduous \\
\hline C. sylvaticus ${ }^{\mathrm{b}, \mathrm{c}}$ & 14 & $4.80-64.00$ & $0.38-0.50$ & $4.17-5127.94$ & Deciduous \\
\hline S. gerrardii ${ }^{\mathrm{a}, \mathrm{d}}$ & 15 & $0.70-92.50$ & $0.51-0.65$ & $0.17-3423.33$ & Evergreen \\
\hline T. dregeana ${ }^{\mathrm{b}, \mathrm{c}}$ & 14 & $2.80-62.00$ & $0.35-0.55$ & $0.82-2357.97$ & Evergreen \\
\hline X. monospora ${ }^{\mathrm{a}, \mathrm{c}}$ & 15 & $2.00-54.50$ & $0.39-0.54$ & $2.61-3816.50$ & Evergreen \\
\hline
\end{tabular}

Note. ${ }^{\mathrm{a}}$ - species with smaller leaf area, ${ }^{\mathrm{b}}$ - species with larger leaf area, ${ }^{\mathrm{c}}$ - species with lower wood density, ${ }^{\mathrm{d}}-$ species with higher wood density.

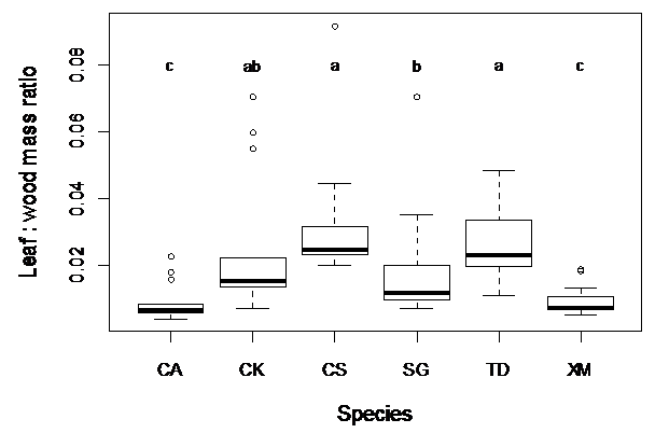

Figure 1 Distribution of leaf to wood mass ratio among studied species; CA - C. africana, CK - C. kraussii, CS - C. sylvaticus, SG - S. gerrardii, TD - T. dregeana, XM - X. monospora. Species with the same letter are not significantly different at $p=0.05$ (Student-Newman-Keuls test).

of LWR due to tree size by using the residuals of LWR-DBH model as response variable, and each specific trait as explanatory variable. Finally, we grouped the species and compared the trend lines of LWR-dbh scaling relationship between groups of species. We used the specific functional traits as a grouping factor, thus distinguishing (1) between species with larger and smaller leaf area, and (2) between species with higher and lower wood density. After grouping, we found that the range for tree diameter was greater in the group of high wood density species $(0.7-94.5 \mathrm{~cm})$. Therefore, we excluded the largest trees from the set of study species to have approximatively the same range of tree diameter within each group, and to fairly compare the trends in LWR-DBH scaling relationship.

\section{Results}

\section{Effects of tree diameter and species identity on biomass partitioning patterns}

Within study species, the biomass allocated to foliage per unit of wood mass (LWR) ranged from 0.0038 to 0.0225 for C. africana, 0.0071 to 0.0704 for $C$. kraussii, 0.0200 to 0.0916 for $C$. sylvaticus, 0.0073 to 0.1443 for $S$. gerrardii, 0.0113 to 0.0485 for $T$. dregeana and 0.0053 to 0.0503 for $X$. monospora (Figure $1)$. There were significant differences between species $(F=13.4 ; P<0.001)$. On average, $C$. sylvaticus and $T$. dregeana showed the highest values of LWR, followed by $C$. kraussii and $S$. gerrardii, while $C$. africana and $X$. monospora had the same and lowest values (Figure 1).

Tree diameter and species identity showed significant effects $(P<0.001)$ on the biomass allocation patterns, with $77.96 \%$ of the total variance being explained (Table 2). Tree diameter alone explained $44.44 \%$ of the variance of LWR for all species $(P<0.001)$. The effect of tree size was shown by a significant decrease in LWR with increasing tree diameter (Figure $2 \mathrm{a}$ ), regardless of the species. Results from GLM also showed species' significant effects 
on the leaf to wood mass ratio $(P<0.001$, Table 2), and a large variability of species-specific slopes. For a given tree diameter, $C$. sylvaticus, T. dregeana, C. kraussii and S. gerrardii showed slopes of $1.27 \pm 0.14,1.13 \pm 0.14$, $0.81 \pm 0.14$ and $0.53 \pm 0.14$ respectively, higher than the one in C. africana, which was considered as the baseline (Table 2). X. monospora was ranked last, and had a slope that did not differ significantly from the one in the baseline $(P=0.320)$.

\section{Effects of leaf area and wood density on biomass partitioning patterns}

Leaf area and specific wood density explained $30.17 \%$ and $12.61 \%$ respectively, of the variance of the leaf to wood mass ratio, after the effect of tree diameter was accounted for. The leaf to wood mass ratio increased significantly $(P<0.001)$ with increasing leaf area (Table 2 ; Figure $2 \mathrm{~b}$ ). Contrary to the leaf area, wood density showed a negative effect on the leaf to wood mass ratio (Table 2; Figure 2c). Figure 3 showed a significant decline in LWR with increasing tree diameter for all species groups (scaling coefficient $<0$, Figures 3a-b). However, the biomass allocated to foliage per unit of wood mass decreased more steeply in higher wood density species (slope $=-5.10^{-4}$ ) than in lower wood density species (slope $=-4.10^{-4}$, Figure 3b). Accordingly, species with higher wood density had slightly lower LWR than species with lower wood density. In contrast, a more remarkable differentiation was noted between species with larger leaf area and species with smaller leaf area (Figures 3b): those with larger leaf area had greater slope and intercept, and therefore greater biomass allocated to foliage per unit of wood biomass.

\section{Discussion}

Our results showed that tree size (diameter) has a strong effect on the aboveground biomass partitioning patterns, as also revealed in other studies (Xie et al. 2012, Poorter et al. 2015). More specifically, LWR declined substantially with increasing tree diameter, regardless of the species. This means that as trees get larger, the production of foliage biomass per unit of wood mass tends to decrease. This outcome accords with other studies that reported for larger trees, an increasing relative contribution of stem and branches with a proportional decrease in the fraction of foliage (e.g. Pajtik et al. 2011, Luo et al. 2014). This is also consistent with the fact that an increase in wood biomass occurs often at the expense of foliage biomass (Helmisaari

Table 2 Output of GLMs describing the effects of tree diameter, species identity, wood density and leaf area on leaf to wood mass ratio

\begin{tabular}{|c|c|c|c|c|c|c|c|}
\hline & Estimate & $S E$ & $t$ & $P(>|t|)$ & Deviance & $P(>$ Chi $)$ & $\begin{array}{c}\text { Pseudo } R \\
\text { square }(\%)\end{array}$ \\
\hline Intercept & -3.092 & 0.164 & -18.896 & $<0.001$ & & & \multirow{8}{*}{77.96} \\
\hline $\log (\mathrm{DBH})$ & -0.525 & 0.041 & -12.769 & $<0.001$ & 24.79 & $<0.001$ & \\
\hline Species & & & & & 18.70 & $<0.001$ & \\
\hline C. kraussii & 0.813 & 0.139 & 5.866 & $<0.001$ & & & \\
\hline C. sylvaticus & 1.273 & 0.143 & 8.893 & $<0.001$ & & & \\
\hline S. gerrardii & 0.533 & 0.141 & 3.777 & $<0.001$ & & & \\
\hline T. dregeana & 1.126 & 0.143 & 7.866 & $<0.001$ & & & \\
\hline X. monospora & 0.141 & 0.141 & 1.001 & 0.320 & & & \\
\hline Intercept & 1.387 & 0.403 & 3.444 & $<0.001$ & & & \multirow{2}{*}{12.61} \\
\hline Wood density & -2.672 & 0.767 & -3.482 & $<0.001$ & 4.11 & $<0.001$ & \\
\hline Intercept & -0.464 & 0.093 & -4.972 & $<0.001$ & & & \multirow{2}{*}{30.17} \\
\hline Leaf area & 0.011 & 0.002 & 6.131 & $<0.001$ & 9.96 & $<0.001$ & \\
\hline
\end{tabular}



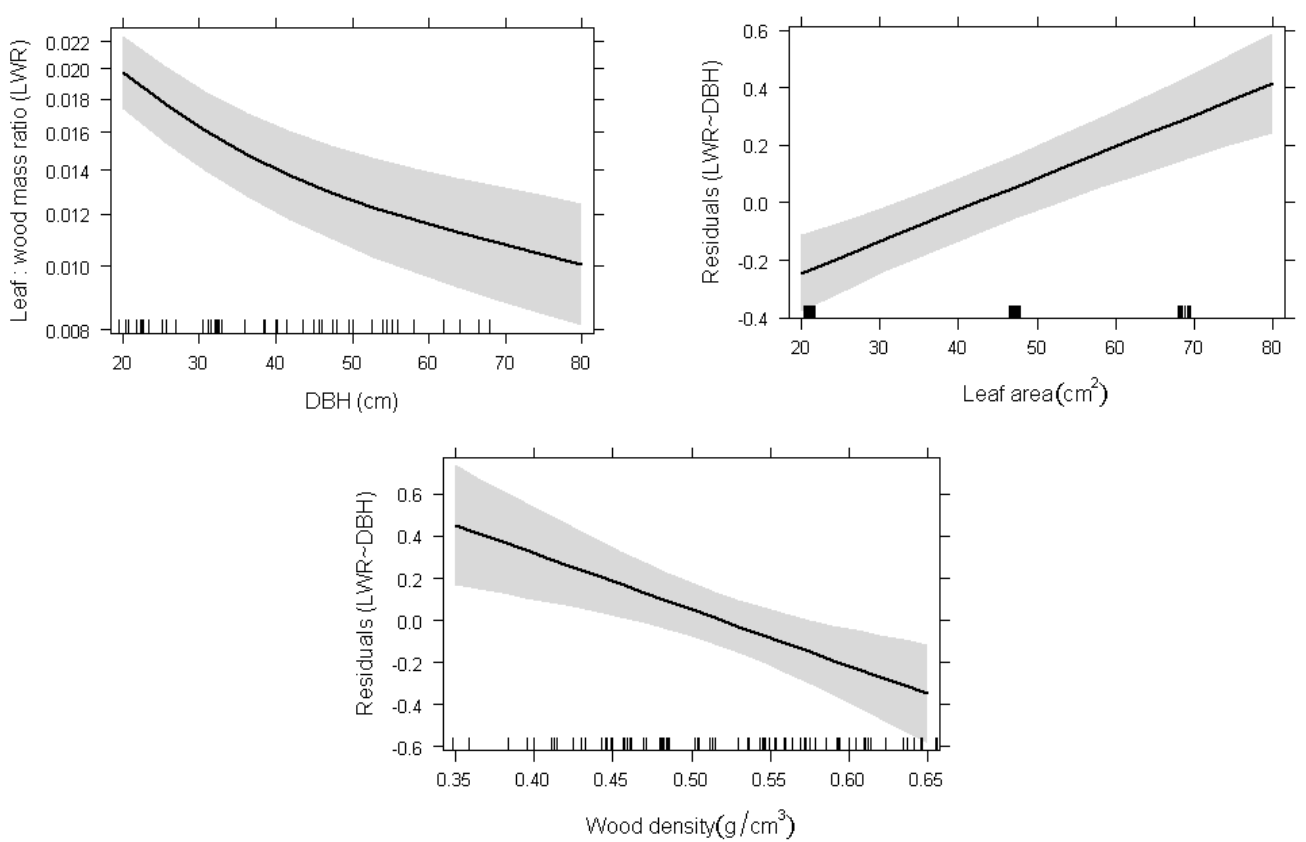

Figure 2 Individual effects of (a) tree size (DBH), (b) leaf area and (c) wood density on leaf to wood mass ratio. The regression coefficients (estimates) and values of pseudo $R$-square are given in Table 2 .

et al. 2002). Such a reduced production of foliage biomass is in part a result of the declining production of branch foliage when branches get older (King 1997). This is intrinsically linked with increasing amount of heartwood in stems and branches with increasing age and in line with the findings that sapwood area is highly correlated with total foliage biomass according to the pipe model theory (Shinozaki et al. 1964a,b, Marchand 1984, Morataya et al. 1999). The higher LWR in younger trees indicates that more carbohydrate resources would have been allocated to foliage to undertake photosynthetic activities and allow rapid vertical growth. In natural environments (e.g. natural forests), it is remarkable that resource partitioning among plant organs at early development stages is part of plant's strategy built as a response of competition for light. But as plant size increases, more resources are allocated for stem growth (height and diameter) to enable plants to compete with conspecific and heterospecific neighbours. In the meantime, additional resources are invested for root growth and for below ground mechanical safety (Poorter et al. 2015). Therefore, increasing tree size would result in different mechanical architectures that enable plants to differentially access the resources in the below and aboveground compartments (Fourcaud et al. 2008). While our results support the hypothesis of size-related allocation patterns, the variance explained by tree diameter leaves much part of variation to be attributed to species-specific differences (Weiner 2004, McCarthy et al. 2007, Poorter et al. 2015), and / or environmental effects (McCarthy \& Enquist 2007, Reich et al. 2014).

The significant effect of species identity on the biomass partitioning patterns stresses the plasticity of different species in acquiring resources and adjusting biomass allocation. Indeed, different species are expected to obtain resources in various ways because of the in- 

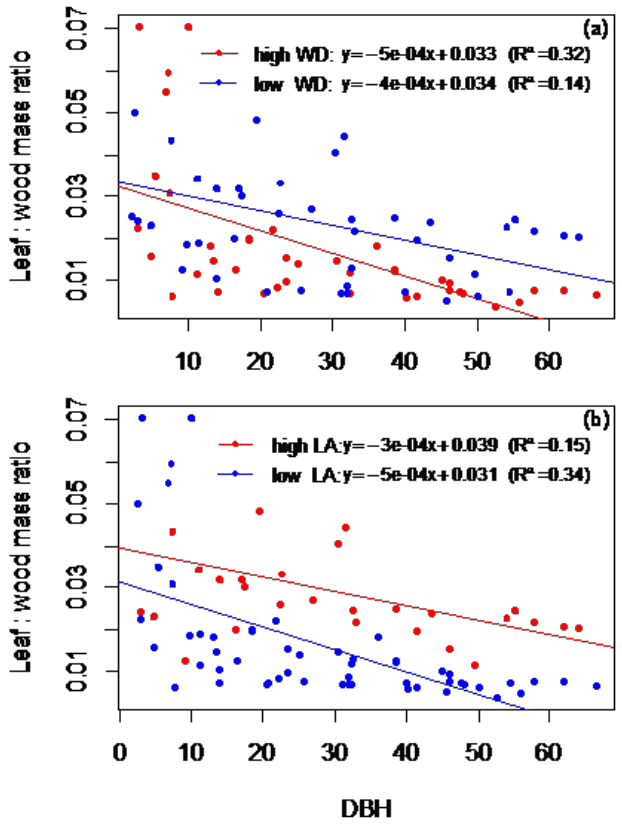

Figure 3 Regression lines fitting the distribution of leaf to wood mass ratio as a function of tree diameter (DBH; $\mathrm{cm})$ in (a) higher and lower wood density (WD) species, and in (b) smaller and larger leaf area (LA) species.

terspecific variation in architectural branching and phenotypic plasticity (Poorter et al. 2006, Fourcaud et al. 2008, Lambers et al. 2006, Jarčuška \& Barna 2011), and in functional traits (Xie et al. 2012, Freschet et al. 2015). For instance, when analysing the individual effect of each species, we found the highest slopes for C. sylvaticus and T. dregeana. From a biological perspective, this result means that, for a given value of trunk diameter, C. sylvaticus and T. dregeana would exhibit higher foliage biomass per unit of wood mass, compared to C. africana, C. kraussii S. gerrardii and $X$. monospora. From a functional perspective, the relatively greater foliage biomass allocated in C. sylvaticus and T. dregeana is likely the result of the effects of functional traits that might be strongly involved in the construction of conductive tissues and the growth of plant.
Our results support the influence of plant functional traits, such as specific wood density and individual leaf area, on biomass allocation. Leaf area showed positive effects on the biomass allocated to foliage per unit of wood mass. Accordingly, species with larger average leaf area exhibited higher LWR than those with smaller leaf area. The leaf area seems to be a good explanatory variable of biomass allocation patterns because it defines not only the extent of interception of radiant energy, but also the absorption of $\mathrm{CO}_{2}$, and facilitates the transfer of water between foliage and atmosphere (Margolis et al. 1995, Leuchner et al. 2012, Priesack et al. 2012, Weraduwage et al. 2015). Our results reinforce the importance of leaf traits for plant performance (Poorter \& Bongers 2006). Specifically, larger leaves have greater potential for light interception and photosynthetic production. If the effect of leaf area can also explain the between-species variation of allocation patterns, then species leaf area should play an important role in determining the capacity of plant to capture aboveground resources (Freschet et al. 2015), and also a crucial role in plant competition.

Leaf to wood mass ratio decreased with increasing wood density. The latter has proved to be a good indicator of the aboveground biomass in many studies (Chave et al. 2014, Wright et al. 2010, Finegan et al. 2015), even though the relation between tree biomass and wood density is not always consistent (Stegen et al. 2009). Pajtik et al. (2011) found significant differences in whole tree biomass between beech, oak and pine species in Slovakia, and related this outcome to a probable effect of wood density. The here-reported influence of wood density could be explained by the fact that low wood density would allow for a faster tree growth (King et al. 2006, Wright et al. 2010), and when tree grows faster, more resources are allocated to the organ responsible for photosynthetic activities, thus stimulating the production of foliage. The faster growth in lower wood density tree is typical for pioneer 
tree species and enables them to fill forest canopy gaps quickly. On the contrary, in higher wood density species, the conductive tissues are most expensive to construct (Suzuki 1999), thus slowing tree growth. Furthermore, it was found that LWR declined with increasing tree size for both higher and lower wood density species, consistently with what is expected from the size dependency hypothesis. However, the fact that LWR declines more steeply in higher wood density species than in lower wood density species indicates that the latter allocates more biomass to foliage and less biomass to stem and branches. This outcome suggests that additional resources have probably been allocated to foliage to maximize photosynthetic activities in low wood density species.

All being considered, it is worth mentioning that co-existing species show quite different patterns of aboveground allocation and different correlations with structural traits. This may serve as proof that competition in the Mistbelt forests is interacting with tree structure and morphology. However, it must be taken into account that the competition in these multi-species forests is complex and that trees might change their competitive abilities during their lifetime as shown in similarly structured Afrotemperate forests (Seifert et al. 2014).

\section{Conclusions}

Tree size was the major influencing variable on biomass allocation between leaves and wood and, species identity (i.e. difference in the species per se) showed clearly differentiable patterns, as response to varying plant functional traits such as leaf area and wood density. Therefore, our study underlines the role of plant size and functional traits in the plasticity of adjustment in biomass allocation, but more importantly, it highlights that neither tree diameter and species identity nor leaf area and wood density are the only important variables to consider if we are to catch the total variability in the biomass allocation patterns. While recent studies put forward the importance of above and belowground resources available, accounting for the role of plant functional traits that could capture the leaf and wood economics spectra, would provide deeper insights into the mechanisms behind resource utilisation and biomass allocation.

\section{Acknowledgements}

This research was partly supported by the SHARE Intra-ACP project and the National Research Foundation of South Africa through the project Catchman Letaba in the RTF funding scheme of DST. Special thanks go to the colleagues Otto Pienaar and Andrew Perkins who provided help during the data collection. We also acknowledge the anonymous referees for their significant contribution.

\section{References}

Bloom A.J., Chapin F.S., Mooney H.A., 1985. Resource limitation in plants - an economic analogy. Annual Review of Ecology and Systematics 16(1): 363-392. DOI: 10.1146/annurev.es.16. 110185.002051

Bonser S.P., Aarssen L.W., 2009. Interpreting reproductive allometry individual strategies of allocation explain size-dependent reproduction in plant populations. Perspectives in Plant Ecology, Evolution and Systematics 11(1): 31-40. DOI: 10.1016/j.ppees. 2008.10.003

Chave J., Réjou-Méchain M., Búrquez A., Chidumayo E., Colgan M.S., Delitti W.B.C., Duque A., Eid T., Fearnside P.M., Goodman R.C., Henry M., Martínez-Yrízar A., Mugasha W.A., Muller-Landau H.C., Mencuccini M., Nelson B.W., Ngomanda A., Nogueira E.M., Ortiz-Malavassi E., Pélissier R., Ploton P., Ryan C.M., Saldarriaga J.G., Vieilledent G., 2014. Improved allometric models to estimate the aboveground biomass of tropical trees. Global Change Biology 20 (10): 31773190. DOI: $10.1111 / \mathrm{gcb} .12629$

Coates-Palgrave M., 2002. Keith Coates-Palgrave Trees of Southern Africa, edn 3, imp. 4 Random House Struik, Cape Town, $1212 \mathrm{p}$.

Deng J.M., Wang G.X., Morris E.C., Wei X.P., Li D.X., Chen B.M., Zhao C.M., Liu J.,Wang Y., 2006. Plant mass-density relationship along a moisture gradient in north-west China. Journal of Ecology 94: 953-958. 
DOI: 10.1111/j.1365-2745.2006.01141.x

Dybzinski R., Farrior C., Wolf A., Reich P.B., Pacala S.W., 2011. Evolutionarily stable strategy of carbon allocation to foliage, wood, and fine roots in trees competing for light and nitrogen: an analytically tractable, individual-based model and quantitative comparisons to data. American Naturalist 177: 153-166. DOI: $10.1086 / 657992$

Finegan B., Peña-Claros M., de Oliveira A., Ascarrunz N., Bret-Harte M.S., Carreño-Rocabado G., Casanoves F., Díaz S., Eguiguren Velepucha P., Fernandez F., Licona J.C., Lorenzo L., Salgado Negret B., Vaz M., Poorter L., 2015. Does functional trait diversity predict aboveground biomass and productivity of tropical forests? Testing three alternative hypotheses. Journal of Ecology 103: 191-201. DOI: 10.1111/1365-2745.12346

Fourcaud T., Zhang X., Stokes A., Lambers H., Körner C., 2008. Plant growth modelling and applications: the increasing importance of plant architecture in growth models. Annals of Botany 101: 1053-1063. DOI: 10.1093/aob/mcn050

Freschet G.T., Kichenin E., Wardle A.D., 2015. Explaining within-community variation in plant biomass allocation: a balance between organ biomass and morphology above vs below ground? Journal of Vegetation Science 26: 431-440. DOI: 10.1111/jvs.12259

Geldenhuys C.J., 2002. Tropical secondary forest management in Africa: Reality and perspectives. South Africa Country Paper.

Helmisaari H.S., Makkonen K., Kellomaki S., Valtonen E., Malkonen E., 2002. Below- and above-ground biomass, production and nitrogen use in Scots pine stands in eastern Finland. Forest Ecology and Management 165: 317-326. DOI: /10.1016/S0378-1127(01) 00648-X

Ivetić V., Stjepanović St., Devetaković J., Stanković D., Škorić M., 2014. Relationships between leaf traits and morphological attributes in one-year bareroot Fraxinus angustifolia Vahl. seedlings. Annals of Forest Research 57(2): 197-203. DOI: 10.15287/afr.2014.214

Jarčuška B., Barna M., 2011. Plasticity in above-ground biomass allocation in Fagus sylvatica L. saplings in response to light availability. Annals of Forest Research 54(2): 151-160.

Kattge J., Diaz S., Lavorel S., Prentice C., Leadley P., Bonisch G. et al., 2011. TRY - a global database of plant traits. Global Change Biology 17: 2905-2935. DOI: 10.1111/j.1365-2486.2011.02451.x

King D.A., 1997. Branch growth and biomass allocation in Abies amabilis saplings in contrasting light environments. Tree Physiology 17: 251-258. DOI: 10.1093/ treephys/17.4.251

King D.A., Davies S.J., Tan S., Noor N.S., 2006. The role of wood density and stem support costs in the growth and mortality of tropical trees. Journal of Ecology 94 : 670-680. DOI: 10.1111/j.1365-2745.2006.01112.x

Körner C., 1994. Biomass fractionation in plants: a reconsideration of definitions based on plant functions. In: Roy J., Garnier E., (eds.), A whole plant perspective on carbon-nitrogen interactions. Academic Publishing, The Hague, the Netherlands, pp. 173-185.

Lambers H., Shane M.W., Cramer M.D., Pearse S.J., Veneklaas E.J., 2006. Root structure and functioning for efficient acquisition of phosphorus: matching morphological and physiological traits. Annals of Botany 98: 693-713. DOI: 10.1093/aob/mcl114

Leuchner M., Hertel C., Rötzer T., Seifert T., Weigt R., Werner H., Menzel A., 2012. Solar radiation as a driver for growth and competition in forest stands. In: Matyssek R., Schnyder H., Ernst D., Munch J-C., Oßwald W., Pretzsch H., (eds.), Growth and defence in plants: resource allocation at multiple scales. Ecological Studies 220, Springer, pp. 175-191. DOI: 10.1007/9783-642-30645-7 8

Luo Y., Zhang X., Wang X., Ren Y., 2014. Dissecting Variation in Biomass Conversion Factors across China's Forests: Implications for Biomass and Carbon Accounting. PLoS ONE 9(4): e94777. DOI: 10.1371/journal. pone. 0094777

Marchand P.J., 1984. Sapwood area as an estimator of foliage biomass and projected leaf area for Abies balsamea and Picea rubens. Canadian Journal of Forest Research 14(1): 85-87. DOI: $10.1139 / x 84-016$

Margolis H., Oren R., Whitehead D., Kaufmann M.R., 1995. Leaf area dynamics of conifer forests. In: Smith W.K., Hinckley T.M., (eds.), Ecophysiology of coniferous forests. Academic Press, San Diego, pp. 255-308. DOI: 10.1016/B978-0-08-092593-6.50012-8

McCarthy M.C., Enquist B.J., 2007. Consistency between an allometric approach and optimal partitioning theory in global patterns of plant biomass allocation. Functional Ecology 21: 713-720. DOI: 10.1111/j.13652435.2007.01276.x

McCarthy M.C., Enquist B.J., Kerkhoff A.J., 2007. Organ partitioning and distribution across the seed plants: assessing the relative importance of phylogeny and function. International Journal of Plant Sciences 168: 751761. DOI: $10.1086 / 513491$

Mokany K., Raison R.J., Prokushkin A.S., 2006. Critical analysis of root: shoot ratios in terrestrial biomes. Global Change Biology 12: 84-96. DOI: /10.1111/j.13652486.2005.001043.x

Morataya R., Galloway G., Berninger F., Kanninen M., 1999. Foliage biomass - sapwood (area and volume) relationships of Tectona grandis L.F. and Gmelina arborea Roxb.: silvicultural implications. Forest Ecology and Management 113 (2-3): 231-239. DOI: 10.1016/ S0378-1127(98)00429-0

Mucina L., Rutherford M.C., 2006. The vegetation of South Africa, Lesotho and Swaziland. Strelitzia 19, South African National Biodiversity Institute, Pretoria, 807 p.

Müller I., Schmid B., Weiner J., 2000. The effect of nutrient availability on biomass allocation patterns in 27 species of herbaceous plants. Perspectives in Plant Ecology, Evolution and Systematics 3(2): 115-127. DOI: $10.1078 / 1433-8319-00007$ 
Ninkovic V., 2003. Volatile communication between barley plants affects biomass allocation. Journal of Experimental Botany 54: 1931-1939. DOI: 10.1093/jxb/ erg 192

Pajtik J., Konopka B., Lukac M., 2011. Individual biomass factors for beech, oak and pine in Slovakia: a comparative study in young naturally regenerated stands. Trees 25: 277-288. DOI: 10.1007/ s00468-010-0504-z

Pearcy R.W., Muraoka H., Valladares F., 2005. Crown architecture in sun and shade environments: assessing function and trade-offs with a three-dimensional simulation model. New Phytologist 166: 791-800. DOI: 10.1111/j.1469-8137.2005.01328.x

Pino J., Sans F.X., Masalles R.M., 2002. Size-dependent reproductive pattern and short-term reproductive cost in Rumex obtusifolius L. Acta Oecologica 23(5): 321-328. DOI: $10.1016 / \mathrm{S} 1146-609 X(02) 01161-X$

Poorter H., Jagodzinski A. M., Ruiz-Peinado R., Kuyah S., Luo Y., Oleksyn J., Usoltsev V. A., Buckley T. N., Reich P. B., Sack L., 2015. How does biomass distribution change with size and differ among species? An analysis for 1200 plant species from five continents. New Phytologist 208: 736-749. doi:10.1111/nph.13571. DOI: $10.1111 / \mathrm{nph} .13571$

Poorter H., Sack L., 2012. Pitfalls and possibilities in the analysis of biomass allocation patterns in plants. Frontiers in plant science 3:259. doi:10.3389/ fpls.2012.00259. DOI: 10.3389/ fpls.2012.00259

Poorter H., Niklas K.J., Reich P.B., Oleksyn J., Poot P., Mommer L., 2012. Biomass allocation to leaves, stems and roots: meta-analyses of interspecific variation and environmental control. New Phytologist 193: 30-50. DOI: $10.1111 /$ j.1469-8137.2011.03952.x

Poorter L., Bongers F., 2006. Leaf traits are good predictors of plant performance across 53 rain forest species. Ecology 87: 1733-1743. DOI: 10.1890/0012-9658(2006)87[1733:LTAGPO]2.0. $\mathrm{CO} ; 2$

Poorter L., Bongers L., Bongers F., 2006. Architecture of 54 moist forest tree species: traits, tradeoffs, and functional groups. Ecology 87: 1289-1301. DOI: $\quad 10.1890 / 0012-9658(2006) 87$ [1289:AOMTST] 2.0.CO;2

Pretzsch H., Dieler J., Seifert T., Rötzer T., 2012. Climate effects on productivity and resource use efficiency of Norway spruce (Picea abies [L.] Karst.) and European beech (Fagus sylvatica [L.]) in stands with different spatial mixing patterns. Trees 26:1343-1360. DOI: $10.1007 / \mathrm{s} 00468-012-0710-y$

Priesack E., Gayler S., Rötzer T., Seifert T., 2012. Mechanistic modelling of soil-plant-atmosphere systems. In: Matyssek R., Schnyder H., Ernst D., Munch J-C., Oßwald W., Pretzsch H., (eds.), Growth and defence in plants: resource allocation at multiple scales. Ecological Studies 220, Springer, pp. 335-353. DOI: 10.1007/9783-642-30645-7_15

Reich P.B., 2002. Root-shoot relations: optimality in acclimation and adaptation or the 'Emperor's New
Clothes"? In: Waisel Y., Eshel A., Kafkafi U., (eds.), Plant roots: the hidden half. Marcel Dekker, Basel, Switzerland, pp. 205-220. DOI: 10.1201/9780203909423. $\operatorname{ch} 12$

Reich P.B., Luo Y., Bradford J.B., Poorter H., Perry C.H., Oleksyn J., 2014. Temperature drives global patterns in forest biomass allocation in leaves, stems and roots. Proceedings of the National Academy of Sciences, USA 111: 13721-13726. DOI: 10.1073/ pnas.1216053111

Rötzer T., Seifert T., Gayler S., Priesack E., Pretzsch H., 2012. Effects of stress and defence allocation defence on tree growth: simulation results at the tree and stand level. In: Matyssek R, Schnyder H, Ernst D, Munch J-C, Oßwald W, Pretzsch H (eds) Growth and Defence in Plants: Resource Allocation at Multiple Scales. Ecological Studies 220, Springer. 401-432.

Seifert T., Seifert S., 2014. Modelling and simulation of tree biomass. In Seifert T., (ed.), Bioenergy from Wood. Springer Netherlands, Dordrecht, pp. 43-65. DOI: 10.1007/978-94-007-7448-3_3

Seifert T., Seifert S., Seydack A., Durheim G., von Gadow K., 2014. Competition effects in an afrotemperate forest. Forest Ecosystems 1:13. DOI: 10.1186/s40663014-0013-4

Seifert T., Müller-Starck G., 2009. Impacts of fructification on biomass production and correlated genetic effects in Norway spruce (Picea abies L. [Karst.]). European Journal of Forest Research 128(2): 155-169. DOI: 10.1007/s10342-008-0219-5

Shinozaki K., Yoda K., Hozumi K., Kira T., 1964a. A quantitative analysis of plant form-the pipe model theory: I. Basic analyses. Japanese Journal of Ecology 14: 97-105.

Shinozaki K., Yoda K., Hozumi K, Kira T., 1964b. A quantitative analysis of plant form-the pipe model theory: II. Further evidence of the theory and its application in forest ecology. Japanese Journal of Ecology 14: 133-139.

Shipley B., Meziane D., 2002. The balanced-growth hypothesis and the allometry of leaf and root biomass allocation. Functional Ecology 16: 326-331. DOI: 10.1046/j.1365-2435.2002.00626.x

Stegen J.C., Swenson N.G., Valencia R., Enquist B.J., Thompson J., 2009. Above-ground forest biomass is not consistently related to wood density in tropical forests. Global Ecology and Biogeography 18: 617-625. DOI: 10.1111/j.1466-8238.2009.00471.x

Suzuki E., 1999. Diversity in specific gravity and water content of wood among Bornean tropical rainforest trees. Ecological Research 14: 211-224. DOI: 10.1046/j.1440-1703.1999.143301.x

Tomlinson K.W., Poorter L., Bongers F., Borghetti F., Jacobs L., van Langevelde F., 2014. Relative growth rate variation of evergreen and deciduous savanna tree species is driven by different traits. Annals of botany 114 (2): 315-324. DOI: 10.1093/aob/mcu107

van Laar A., Akça A., 2007. Forest mensuration. Springer Netherlands, Dordrecht, 383 p. DOI: 10.1007/978-14020-5991-9 
Weiner J., 2004. Allocation, plasticity and allometry in plants. Perspectives in Plant Ecology, Evolution and Systematics 6: 207-215. DOI: 10.1078/1433-831900083

Weraduwage S.M., Chen J., Anozie F.C., Morales A., Weise S.E., Sharkey T.D., 2015. The relationship between leaf area growth and biomass accumulation in Arabidopsis thaliana. Frontiers in Plant Science 6:167. DOI: $10.3389 /$ fpls.2015.00167

Wilson J.B., 1988. A review of evidence on the control of shoot: root ratio, in relation to models. Annals of Botany $61: 433-449$.
Wright S.J., Kitajima K., Kraft N.J.B., Reich P.B., Wright I.J., Bunker D.E., Condit R., Dalling J.W., Davies S.J., Díaz S., Engelbrecht B.M.J., Harms K.E., Hubbell S.P., Marks C.O., Ruiz-Jaen M.C., Salvador C.M., Zanne A.E., 2010., Functional traits and the growth-mortality trade-off in tropical trees. Ecology 91: 3664-3674. DOI: 10.1890/09-2335.1

Xie J., Tang L., Wang Z., Xu G., Li Y., 2012. Distinguishing the biomass allocation variance resulting from ontogenetic drift or acclimation to soil texture. PLoS ONE 7(7): e41502. DOI: 10.1371/ journal.pone.0041502 